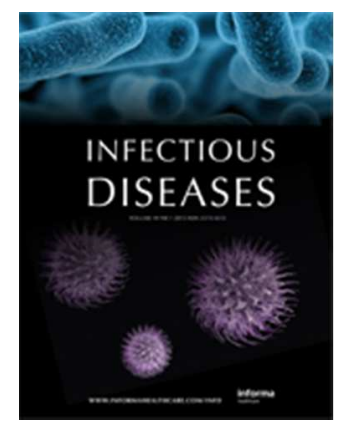

\title{
Asymptomatic faecal carriage of ESBL producing Enterobacteriaceae in Hungarian healthy individuals and in long-term care applicants: a shift towards CTX-M producers in the community
}

\begin{tabular}{|c|c|}
\hline Journal: & Infectious Diseases \\
\hline Manuscript ID & SINF-2015-0728.R3 \\
\hline Manuscript Type: & Brief Report \\
\hline Date Submitted by the Author: & $10-F e b-2016$ \\
\hline Complete List of Authors: & $\begin{array}{l}\text { Ebrahimi, Fatemeh; University of Debrecen, Dept. of Medical Microbiology } \\
\text { Mózes, Julianna; University of Debrecen, Dept. of Medical Microbiology } \\
\text { Mészáros, Júlia; Synlab Ltd, Microbiology Debrecen } \\
\text { Juhász, Ágnes; Synlab Ltd, Microbiology Debrecen } \\
\text { Majoros, László; University of Debrecen, Dept. of Medical Microbiology } \\
\text { Szarka, Krisztina; University of Debrecen, Dept. of Medical Microbiology } \\
\text { Kardos, Gábor; University of Debrecen, Dept. of Medical Microbiology }\end{array}$ \\
\hline Keywords: & $\begin{array}{l}\text { extended-spectrum beta-lactamases, Klebsiella pneumoniae, Escherichia } \\
\text { coli }\end{array}$ \\
\hline
\end{tabular}

\section{SCHOLARONE ${ }^{\prime \prime}$ \\ Manuscripts}


1 Asymptomatic faecal carriage of ESBL producing Enterobacteriaceae in Hungarian healthy individuals

2 and in long-term care applicants: a shift towards CTX-M producers in the community

3

4 Fatemeh Ebrahimi ${ }^{1}$, Julianna Mózes ${ }^{1}$, Júlia Mészáros ${ }^{2}$, Ágnes Juhász ${ }^{2}$, László Majoros ${ }^{1}$, Krisztina

5 Szarka $^{1}$, Gábor Kardos ${ }^{1}$

$6 \quad{ }^{1}$ Department of Medical Microbiology, University of Debrecen, Debrecen, Hungary

$7 \quad{ }^{2}$ Synlab Ltd., Microbiology Debrecen, Debrecen, Hungary

8

9 Keywords: extended-spectrum beta-lactamases, Klebsiella pneumoniae, Escherichia coli

10 Running title: Changing epidemiology of faecal ESBL carriage

11

12 Correspondence to

13 G. Kardos

14 Department of Medical Microbiology

15 University of Debrecen

16 H-4032, Debrecen, Nagyerdei krt. 98., Hungary

17 Tel: $+36-52-255-425$

18 Fax: $+36-52 / 255 / 424$

19 Email: $\underline{\mathrm{kg} @ \text { med.unideb.hu }}$

20

21 Declaration of interest: The study itself received no financial support. G. Kardos and J. Mózes were 22 supported by scholarships TÁMOP 4.2.4. A/2-11-1-2012-0001 „National Excellence Program 23 Elaborating and operating an inland student and researcher personal support system". There is no conflict 24 of interest regarding the manuscript.

25 


\section{Abstract}

27 Background: Faecal carriage of extended-spectrum beta- lactamase (ESBL) producing Enterobacteriaceae

28 in healthy individuals was examined and compared to previous results obtained in such individuals a few 29 years earlier.

30 Methods: Faecal samples from 779 individuals screened for employment purposes and from 225 31 applicants to long-term care (LTC) were screened between November 2013 and May 2014.

32 Results: The overall rate of fecal carriage was 3.0\% (30/1004). The carriage rate was significantly higher 33 in applicants for LTC (5.3\% vs. 2.3\%; p=0.019). All isolates carried CTX-M ESBLs, with an 34 overwhelming dominance of bla $a_{\mathrm{CTX}-\mathrm{M}-15}(84.4 \%)$ in both groups and in both E. coli and Klebsiella 35 pneumoniae.

36 Conclusions: The prevalences were comparable to those in the earlier study, but a marked decrease of the 37 diversity of ESBL genes in E. coli from the employment screening group was found, suggesting that the 38 ESBL-producing isolates originating from diverse sources are being replaced by highly successful $b l a_{\mathrm{CTX}}$ 39 M-15 producing strains. 
41 Introduction

42 The gut flora of humans and animals is undoubtedly a significant reservoir of plasmids harbouring ESBL

43 genes as well as of ESBL producers [1] and may serve as a source of endogeneous or exogeneous

44 infections [2]. A change in the epidemiology of ESBL producing Enterobacteriaceae took place when

45 CTX-M-type enzymes became prevalent first in the hospital and then in the community setting. Their

46 high ability to disperse locally in the community [3] and to disperse long-range via international travel [4]

47 has been reported. Asymptomatic carriers play an increasingly important role in the epidemiology of

48 ESBL producers. It is, therefore, important to monitor changes in the prevalence, distribution and

49 dynamics of ESBL producers not only in infected patients, but in asymptomatic carriers as well. The aim

50 of the present study was to survey the faecal carriage rate of ESBL producers among healthy individuals

51 and to compare with results obtained in the same population a few years earlier [5].

52 
53 Material and methods

54 Stool samples from 779 healthy individuals screened for employment purposes (599 females, 180 males;

55 median age 34 (range 14-61) years) and from 225 applicants to long-term care (LTC) facilities (140

56 females, 85 males; median age 81 (range 0-103) years) were analysed between November 2013 and May

572014 and compared with results obtained in 2009-2010 in the same population. As the study involved

58 only the samples sent for routine screening purposes and the patients were unidentified, informed consent

59 could not be obtained and and approval by an Ethics Review Board was not required.

60 To screen for ESBL production, faecal samples were inoculated onto eosin methylene blue agar plates

61 supplemented with $2 \mathrm{mg} / \mathrm{l}$ cefotaxime. Confirmation of ESBL phenotype was performed using double

62 disk synergy test (Oxoid, Basingstoke, UK). The isolates were identified by MALDI Biotyper (Bruker,

63 Bremen, Germany) and by species-specific PCRs. Susceptibility to ertapenem, meropenem, imipenem,

64 cefotaxime, ceftazidime, cefepime, ciprofloxacin, co-trimoxazole, colistin, amikacin, gentamicin and

65 tobramycin was tested by disk diffusion according to EUCAST recommendations. All isolates were

66 screened for the genes $b l a_{\mathrm{TEM}}, b l a_{\mathrm{SHV}}$, and $b l a_{\mathrm{CTX}-\mathrm{M}}$, amplified genes were sequenced. Five

67 aminoglycoside resistance genes $a a c\left(3^{\prime}\right)-I I a, a a c\left(6^{\prime}\right)-I b, a p h\left(3^{\prime}\right)-I a$, ant(2”)-Ia, ant(3”)-Ia, and class 1

68 and 2 integrons were sought for by PCRs. Gene cassette arrays were determined by sequencing. For

69 Escherichia coli phylogenetic group and the clone O25b-ST131 were determined by PCRs. All technical

70 protocols were described in our earlier publication [5]. Prevalences of isolates or genes were compared by

71 chi-square or Fisher's exact test as appropriate using PaSt 3.0.

72 
73 Results and discussion

74 The overall rate of fecal carriage of ESBL-producing isolates was 3.0\% (30/1004). The carriage rate was 75 significantly higher in applicants for LTC than in the employment screening group (5.3\%, 12/225 vs. $762.3 \%, 18 / 779 ; \mathrm{p}=0.019)$. Thirty-two isolates produced ESBLs. Only E. coli isolates were found in the 77 employment screening group, while in applicants for LTC five persons carried E. coli, another five 78 carried K. pneumoniae, and further two carried both species simultaneously.

79 All isolates carried CTX-M type ESBLs with an overwhelming dominance of bla $a_{\mathrm{CTX}-\mathrm{M}-15}$ (Table I). 80 Diversity of ESBL genes was low. All K. pneumoniae isolates carried bla ${ }_{\text {CTX-M-15 }}$ (two of them harboured $81 b l a_{\mathrm{SHV}-5}$ and two other $b l a_{\mathrm{SHV}-110}$ simultaneously), while six of seven $E$. coli isolates from the LTC group

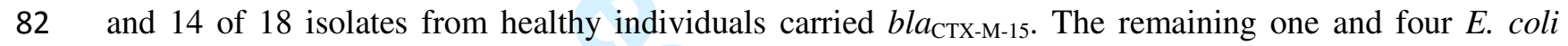
83 isolates carried $b l a_{\mathrm{CTX}-\mathrm{M}-1}$.

84 Resistance to other antibiotic classes than beta-lactamases was common. Eleven, twelve, eight and 13 of 8514 isolates were resistant to ciprofloxacin, co-trimoxazole, gentamicin and amikacin, respectively, in the 86 LTC group, while these numbers were eleven, eleven, six and six of 18 isolates in healthy individuals. 87 This difference in susceptibility to amikacin was also evident when comparing only E. coli isolates. 88 Integron carriage rates were comparable. In the LTC group class 1 integrons were detected in four $K$. 89 pneumoniae (three and one with gene cassette arrays $d f r A 12-o r f X-a n t(3$ ”)-Ib and $d f r A 15$-ant(3")-Ia, 90 respectively) and three E. coli (one and two with gene cassette arrays $d f r A 7$ and $d f r A 17-a n t(3$ ”)-Ie, 91 respectively). Among E. coli isolates from healthy individuals six were class 1 integron carriers with one $92 d f r A 7$, one $d f r A 1-\operatorname{ant}(3$ ")-Ia, two $\operatorname{ant}(3$ ")-Ia and two $d f r A 17-\operatorname{ant}(3$ ")-Ie gene cassette arrays. Class two 93 integrons were found only in E. coli, one from the LTC and two from the employment screening group

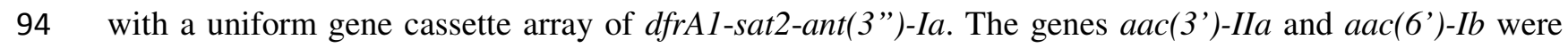
95 more frequently found in the LTC group than in healthy individuals (10/14 vs. 2/18, $\mathrm{p}=0.001$ and $5 / 14$ vs. $960 / 18, \mathrm{p}=0.02$, respectively). This applied when comparing only E. coli isolates from the two groups (5/7 97 vs. $2 / 18, \mathrm{p}=0.007$ and $3 / 7$ vs. $0 / 18, \mathrm{p}=0.015$, respectively). Phylogroup distributions were comparable; 
98 dominance of the pathogenic phylogroup B2 was found in the healthy individuals. All phylogroup B2

99 isolates in both groups belonged to the $b l a_{\mathrm{CTX}-\mathrm{M}-15}$ producer $\mathrm{O} 25 \mathrm{~b}: \mathrm{ST} 131$ pandemic clone.

100 Compared with the 2009-2010 study [5], the over-all prevalence of ESBL producers was slightly lower.

101 Though the prevalences of the two periods were statistically comparable, there was a significant 102 difference between the overall gene distributions in the two periods as well as between gene distribution 103 in the employment screening group. K. pneumoniae, found exclusively in the LTC group in both periods, 104 became uniformly positive for $b l a_{\mathrm{CTX}-\mathrm{M}-15}$. Thus, production of SHV enzymes by K. pneumoniae became 105 linked to simultaneous production of $b l a_{\text {СTX-M-15. }}$ Remarkably, carbapenem (ertapenem) resistance, which 106 appeared in K. pneumoniae isolated from inpatients in the same region [6], has not yet emerged.

107 Similarly, in E. coli from the LTC group the gene $b l a_{\text {СтХ-M-15 }}$ became slightly more frequent (16/21 vs. 108 6/7), and became predominant in healthy individuals as well, but this difference was not statistically 109 significant. In the earlier study five of 22 isolates and in the present study 14 of 18 isolates carried $b l a_{\mathrm{CTX}}$ 110 M-15 (Table I). This change was paralleled by increased resistance to ciprofloxacin and amikacin together 111 with more frequent carriage of $a a c\left(3^{\prime}\right)-I I a$ and $a a c\left(6^{\prime}\right)-I b$, co-resistances and genes commonly associated 112 with $b l a_{\mathrm{CTX-M-15}}[7,8]$. There was s significant difference in $b l a_{\mathrm{CTX-M-15}}$ carriage between the LTC group and 113 the employment screening group in the first period [5] but not in the second period. The similarity 114 between the two groups in the present study suggests a scenario where the hospital based CTX-M-15 115 producers have been established in the non-hospitalized group, i.e. in the community.

116 Several studies report the emergence of $b l a_{\text {СтХ-М-15 }}$ producing $E$. coli in infections both in the hospital and 117 in the community setting $[9,10]$. Assuming, as in the earlier study, that individuals in the LTC group are 118 highly likely to have an extensive history of hospitalization in contrast to healthy individuals, the present 119 study reports a direct observation of this emergence in asymptomatic carriers. This is underlined by the 120 marked decrease of the diversity of ESBL genes in E. coli from the healthy individuals, where out of the 121 six $b l a_{\text {СтХ-м }}$ enzymes representing all four major groups found in 2009-2010, only the bla $a_{\text {СТХ-м-15 }}$ and $122 b l a_{\text {СтX-M-1 }}$ from group 1 remained in 2013-2014. This suggests that the ESBL-producing isolates 123 originating from diverse sources [11-16], are being replaced by highly successful bla $a_{\mathrm{CTX}-\mathrm{M}-15}$ producing 
2

3

4

5

6

7

8

9
124 strains. This epidemiological shift is confirmed by the replacement of commensal phylogroups by 125 phylogroup B2 and is in parallel with the increase of the proportions of $b l a_{\mathrm{CTX}-\mathrm{M}-15}$ producers in both $E$. 126 coli and $K$. pneumoniae isolated from inpatients from the same geographical area [6].

127 Whether the community is the source or the target for these strains is debated. In some populations the 128 importance of importation to the hospital has been shown [17-19], while previous hospitalization [20] as 129 well as long-term care [5], are risk factors. In the geographical area of the study, exportation of bla $a_{\text {CTX-M-15 }}$ 130 producing (phylogroup B2) E. coli isolates from the hospital to the community followed by spread within 131 the community seems to take place, as suggested by the scenario outlined above. 
1

2

3

4

5

6

7

8

9

10

11

12

13

14

15

16

17

18

19

20

21

22

23

24

25

26

27

28

29

30

31

32

33

34

35

36

37

38

39

40

41

42

43

44

45

46

47

48

49

50

51

52

53

54

55

56

57

58

59

60

133 Acknowledgments

134 The help of the technicians of the Synlab Ltd. during screening work is gratefully acknowledged. 135 
References

137 1. Woerther PL, Angebault C, Jacquier H, Hugede HC, Janssens AC, Sayadi S, et al. Massive increase, 138 spread, and exchange of extended spectrum beta-lactamase-encoding genes among intestinal 139 Enterobacteriaceae in hospitalized children with severe acute malnutrition in Niger. Clin Infect Dis $140 \quad 2011 ; 53: 677-85$

141 2. Damjanova I, Tóth A, Pászti J, Jakab M, Milch H, Bauernfeind A, et al. Epidemiology of SHV-type 142 beta-lactamase-producing Klebsiella spp. from outbreaks in five geographically distant Hungarian 143 neonatal intensive care units: widespread dissemination of epidemic R-plasmids. Int J Antimicrob Agents $144 \quad 2007 ; 29: 665-71$.

145 3. Valverde A, Grill F, Coque TM, Pintado V, Baquero F, Cantón R, et al. High rate of intestinal 146 colonization with extended-spectrum-beta-lactamase-producing organisms in household contacts of 147 infected community patients. J Clin Microbiol 2008;46:2796-9.

148 4. Van der Bij AK, Pitout JD. The role of international travel in the worldwide spread of multiresistant 149 Enterobacteriaceae. J Antimicrob Chemother 2012;67:2090-100.

150 5. Ebrahimi F, Mózes J, Mészáros J, Juhász Á, Kardos G. Carriage rates and characteristics of 151 Enterobacteriaceae producing extended-spectrum beta-lactamases in healthy individuals: comparison of 152 applicants for long-term care and individuals screened for employment purposes. Chemotherapy $153 \quad 2014 ; 60: 239-49$.

154 6. Ebrahimi F, Mózes J, Monostori J, Gorácz O, Fésűs A, Majoros L, et al. Comparison of the faecal 155 colonization rates with extended-spectrum beta-lactamase producing enterobacteria among patients in 156 different wards, outpatients and screened medical students. (submitted).

157 7. Hansen DS, Schumacher H, Hansen F, Stegger M, Hertz FB, Schønning K, et al. Extended-spectrum 158 beta-lactamase (ESBL) in Danish clinical isolates of Escherichia coli and Klebsiella pneumoniae: 159 prevalence, beta-lactamase distribution, phylogroups, and co-resistance. Scand J Infect Dis 2012;44:17416081. 
161 8. Pitout JD, Hanson ND, Church DL, Laupland KB. Population-based laboratory surveillance for 162 Escherichia coli-producing extended-spectrum beta-lactamases: importance of community isolates with $163 \quad$ bla $_{\text {CTX-M }}$ genes. Clin Infect Dis 2004;38:1736-41.

164 9. Hu F, O'Hara JA, Rivera JI, Doi Y. Molecular features of community-associated extended-spectrum- $\beta$ 165 lactamase-producing Escherichia colistrains in the United States. Antimicrob Agents 166 Chemother 2014;58:6953-7.

167 10. Smet A, Martel A, Persoons D, Dewulf J, Heyndrickx M, Claeys G, et al. Characterization of 168 extended-spectrum beta-lactamases produced by Escherichia coli isolated from hospitalized and 169 nonhospitalized patients: emergence of CTX-M-15-producing strains causing urinary tract infections. 170 Microb Drug Resist 2010;16:129-34.

171 11. De Boeck H, Miwanda B, Lunguya-Metila O, Muyembe-Tamfum JJ, Stobberingh E, Glupczynski Y, 172 et al. ESBL-positive Enterobacteria isolates in drinking water. Emerg Infect Dis 2012;18:1019-20.

173 12. Geser N, Stephan R, Hächler H. Occurrence and characteristics of extended-spectrum $\beta$-lactamase 174 (ESBL) producing Enterobacteriaceae in food producing animals, minced meat and raw milk. BMC Vet $175 \operatorname{Res} 2012 ; 8: 21$.

176 13. Literak I, Dolejska M, Janoszowska D, Hrusakova J, Meissner W, Rzyska H, et al. 2010. Antibiotic177 resistant Escherichia coli bacteria, including strains with genes encoding the extended-spectrum beta178 lactamase and QnrS, in waterbirds on the Baltic Sea Coast of Poland. Appl Environ Microbiol $179 \quad 2010 ; 76: 8126-34$.

180 14. Tacão M, Moura A, Correia A, Henriques I. Co-resistance to different classes of antibiotics among 181 ESBL-producers from aquatic systems. Water Res 2014;48:100-7.

182 15. Tóth A, Juhász-Kaszanyitzky É, Mag T, Hajbel-Vékony G, Pászti J, Damjanova I. Characterization of 183 extended-spectrum $\beta$-lactamase (ESBL) producing Escherichia coli strains isolated from animal and 184 human clinical samples in Hungary in 2006-2007. Acta Microbiol Immunol Hung 2013;60:175-85.

185 16. Wieler LH, Ewers C, Guenther S, Walther B, Lübke-Becker A. Methicillin-resistant staphylococci 186 (MRS) and extended-spectrum beta-lactamases (ESBL)-producing Enterobacteriaceae in companion 
187 animals: nosocomial infections as one reason for the rising prevalence of these potential zoonotic 188 pathogens in clinical samples. Int J Med Microbiol 2011;301:635-41.

189 17. Ben-Ami R, Schwaber MJ, Navon-Venezia S, Schwartz D, Giladi M, Chmelnitsky I, et al. Influx of 190 extended-spectrum beta-lactamase-producing enterobacteriaceae into the hospital. Clin Infect 191 Dis 2006;42:925-34.

192 18. Bert F, Larroque B, Paugam-Burtz C, Dondero F, Durand F, Marcon E, et al. Pretransplant fecal 193 carriage of extended-spectrum $\beta$-lactamase-producing Enterobacteriaceae and infection after liver 194 transplant, France. Emerg Infect Dis 2012;18:908-16.

195 19. Harris AD, McGregor JC, Johnson JA, Strauss SM, Moore AC, Standiford HC, et al. Risk factors for 196 colonization with extended-spectrum beta-lactamase-producing bacteria and intensive care unit 197 admission. Emerg Infect Dis 2007;13:1144-9.

198 20. Doi Y, Park YS, Rivera JI, Adams-Haduch JM, Hingwe A, Sordillo EM, et al. Community-associated 199 extended-spectrum $\beta$-lactamase-producing Escherichia coli infection in the United States. Clin Infect 200 Dis 2013;56:641-8.

201

202

203

204

205

206

207

208

209

210

211

212 
213 Table I. Comparison of the prevalence of ESBL and $b l a_{\mathrm{CTX}-\mathrm{M}-15}$ in the present study with an earlier study

214 from the same population in the same region [5]

\begin{tabular}{|c|c|c|c|}
\hline & $\begin{array}{c}2009-10 \\
\text { [reference 5] }\end{array}$ & present study & $\begin{array}{l}\text { probability } \\
(\mathrm{P})\end{array}$ \\
\hline Prevalence of ESBL in LTC & $38 / 531(7.2 \%)$ & $12 / 225(5.3 \%)$ & NS \\
\hline $\begin{array}{c}\text { Prevalence of ESBL in employment } \\
\text { screening group }\end{array}$ & $22 / 1109(2.0 \%)$ & $18 / 779(2.3 \%)$ & NS \\
\hline $\begin{array}{l}\text { Proportion of } b l a_{\mathrm{CTX}-\mathrm{M}-15} \text { producers } \\
\text { among ESBL producers }\end{array}$ & $34 / 63(54.0 \%)$ & $27 / 32(84.4 \%)$ & 0.003 \\
\hline $\begin{array}{c}\text { Proportion of bla } a_{\mathrm{CTX}-\mathrm{M}-15} \text { producing } K . \\
\text { pneumoniae }\end{array}$ & $11 / 18$ & $7 / 7$ & NS \\
\hline $\begin{array}{c}\text { Proportion of bla }{ }_{\text {CTX-M-15 }} \text { producing } E \text {. } \\
\text { coli in LTC group }\end{array}$ & $16 / 21$ & $6 / 7$ & NS \\
\hline $\begin{array}{l}\text { Proportion of bla }{ }_{\text {CTX-M-15 }} \text { producing } E \text {. } \\
\text { coli in healthy individuals }\end{array}$ & $5 / 22$ & $14 / 18$ & $<0.001$ \\
\hline
\end{tabular}

215

216 LTC: Long-term care; NS: not significant 